\title{
Redactioneel
}

\section{0 jaar kinderrechten: zoeken naar nieuw elan, betrokkenheid en inclusiviteit}

\author{
Prof. dr. mr. T. (Ton) Liefaard en mr. T.B. (Tamara) Trotman*
}

\begin{abstract}
'In the 30 years since the adoption of the Convention on the Rights of the Child, the lives of millions of children have been improved through its implementation and the progressive realization of children's rights as enshrined mithin the Convention and its Optional Protocols. It is a moment for bold action to ensure me leave no child behind, and to support every child to reach their full potential.'
\end{abstract}

Uit de mede door de Nederlandse staat ondertekende Global Pledge ter gelegenheid van het 30 -jarig bestaan van het Kinderrechtenverdrag.

De aanleiding voor deze special was de $30 \mathrm{e}$ verjaardag van het Internationale Verdrag inzake de Rechten van het Kind (IVRK), op 20 november 2019. Er was in november zeker reden tot feest. Er is wereldwijd veel bereikt in de afgelopen dertig jaar. Veel landen hebben hun wetgeving aangepast of zelfs compleet nieuwe wetgeving ontwikkeld. In toenemende mate is rechtspraak ontstaan op nationaal en regionaal niveau, waarin kinderrechten nader zijn uitgewerkt en gespecificeerd. En er is duidelijk sprake van een enorme toename in de bewustwording rondom de rechten van het kind, onder beleidsmakers, advocaten, officieren van justitie, rechters, politieagenten, onderwijzers, hulpverleners, wetenschappers, studenten en jongeren zelf. In de afgelopen dertig jaar hebben gouvernementele en niet-gouvernementele organisaties zich beziggehouden met voorlichtings- en trainingsactiviteiten; later kwamen daar ook kinderombudsmannen bij. Ook universiteiten en andere

\footnotetext{
Prof. dr. mr. T. Liefaard, gastredacteur voor dit nummer, is vice-decaan en hoogleraar kinderrechten, houder van de UNICEF-leerstoel kinderrechten aan de Faculteit der Rechtsgeleerdheid van de Universiteit Leiden. Mr. T.B. Trotman is raadsheer bij het Gerechtshof Den Haag.
}

kennisinstellingen zijn zich meer gaan richten op onderzoek en onderwijs op het terrein van kinderrechten, zij het nog in bescheiden mate.

Deze ontwikkelingen hebben ook een sterke invloed gehad op het jeugdstrafrecht, wereldwijd en in Nederland. In de eerste plaats zien we dat het IVRK onderdeel is geworden van een omvangrijk en gedetailleerd juridische kinderrechtenkader, specifiek voor het jeugdstrafrecht dat zich de afgelopen dertig jaar heeft ontwikkeld op het niveau van de Verenigde Naties en regionale mensenrechtensystemen. ${ }^{1}$ In Europa heeft de Raad van Europa, met als onderdeel daarvan het Europese Hof voor de Rechten van de Mens (EHRM), een belangrijke rol gespeeld in het nader concretiseren van de rechten van jeugdige verdachten. Zo heeft bijvoorbeeld het EHRM eind jaren negentig het recht van jeugdige verdachten op effectieve participatie tijdens het onderzoek ter terechtzitting erkend als onderdeel van het recht op een eerlijk proces. Dit heeft de basis gelegd voor de ontwikkeling van de Europese Guidelines on child-friendly justice, die richtlijnen geven over onder meer informatie aan jeugdige verdachten, participatie tijdens strafrechtelijke procedures en rechtsbijstand. ${ }^{2}$ Wat rechtsbijstand betreft kan ook worden gewezen op de Salduz-rechtspraak, en Richtlijn (EU) 2016/800 betreffende procedurele waarborgen voor kinderen die verdachte of beklaagde zijn in een strafprocedure. En regelgeving over de rechtspositie van jongeren die van hun vrijheid zijn beroofd, heeft eveneens het licht

1. U. Kilkelly \& T. Liefaard, 'International Children's Rights: Reflections on a Complex, Dynamic, and Relatively Young Area of Law', in: U. Kilkelly \& T. Liefaard (red.), International Human Rights of Children, Singapore: Springer Nature 2019, p. 617-627.

2. T. Liefaard \& U. Kilkelly, 'Child-Friendly Justice: Past, Present and Future in Juvenile Justice', in: B. Goldson (ed.) Europe: Past, Present and Future, Routledge 2019. 
gezien onder invloed van onder meer het IVRK en de UN Rules for the Treatment of Fuveniles Deprived of Liberty (Havana Rules), zoals de European Rules for juvenile offenders subject to sanctions or measures. ${ }^{3}$

In de tweede plaats zien we dat veel landen hun strafrechtsystemen veel beter hebben laten aansluiten bij de uitgangspunten van het IVRK, met de nadruk op pedagogiek in plaats van repressie, op het gebruik van buitengerechtelijke afdoening en op terughoudendheid bij het gebruik van detentie. Het gebruik van buitengerechtelijke afdoening is enorm toegenomen. Het aantal jongeren in detentie in het kader van het jeugdstrafrecht is enorm afgenomen, zoals ook de recente VN-studie naar vrijheidsbeneming van kinderen laat zien. ${ }^{4}$ En een behoorlijk aantal landen heeft de leeftijdsgrens voor strafrechtelijke aansprakelijkheid verhoogd, vaak naar veertien jaar of hoger. Deze laatste ontwikkeling is onder meer toe te schrijven aan het VN-Kinderrechtencomité, dat landen specifiek aanspreekt op het belang van een leeftijdsgrens die rekening houdt met de verminderde toerekeningsvatbaarheid van kinderen, hun (ontwikkelings)behoeften en hun capaciteiten om te participeren in procedures. Zeer recent heeft het comité daarbij de lat verhoogd van ten minste twaalf jaar naar ten minste veertien jaar en heeft hiertoe reden gezien in wetenschappelijke kennis over de ontwikkeling van jongeren en in het feit dat veel landen in de wereld inmiddels een dergelijke leeftijdsgrens kennen. ${ }^{5}$

Ook in Nederland sluit het jeugdstrafrecht in grote mate aan bij internationale kinderrechten. Nederland heeft al lange tijd een apart jeugdstrafrecht en diende de afgelopen jaren regelmatig als voorbeeld voor andere landen, vooral waar het gaat om de buitengerechtelijke afdoening, het gebruik van evidence based interventies en de rol en invloed van multidisciplinaire rapportages. ${ }^{6}$ Tegelijkertijd zien we een zekere starheid met betrekking tot de bereidheid (en vooral afwezigheid ervan) om het Nederlandse jeugdstrafrecht volledig(er) in overeenstemming te brengen met het IVRK. Nederland blijft bijvoorbeeld vasthouden aan de voorbehouden bij het IVRK, ondanks herhaalde oproepen vanuit de VN om deze los te laten. ${ }^{7}$ Ook is op andere thema's een zekere halsstarrigheid te zien, bij de wetgever, beleidsmakers

3. Zie bijv. T. Liefaard \& Y. van den Brink, 'Juveniles' Right to Counsel During Police Interrogations: An Interdisciplinary Analysis of a YouthSpecific Approach, with a Particular Focus on the Netherlands', Erasmus Law Review 2014, Vol. 7., No. 4.

4. United Nations Global Study on Children Deprived of Liberty, UN Doc. A/74/136, 11 July 2019.

5. CRC Committee, General Comment No. 24 (2019) on children's rights in the child justice system, CRC/C/GC/24, 18 September 2019.

6. Gebaseerd op de diverse ervaringen van de auteur(s) met buitenlandse kinderrechtenprojecten, waarin Nederland werd aangemerkt of gebruikt als voorbeeld. Zie ook bijv. F. Zimring, M. Langer \& D. Tanenhaus (eds.), Juvenile Justice in Global Perspective, New York University Press 2015.

7. Zie o.m. VN-Kinderrechtencomité, Concluding observations on the fourth periodic report of the Netherlands, CRC/C/NDL/CO/4, 8 juni 2015. Voor het jeugdstrafrecht heeft Nederland een voorbehoud gemaakt ten aanzien van art. 37(c) CRC en art. 40 CRC, o.m. ten behoeve van de mogelijkheid om het strafrecht voor volwassenen toe te passen op 16- of 17-jarigen. Ook behoudt de Nederlandse regering zich en hogere rechtspraak, om het jeugdstrafrecht verder te innoveren en daarmee meer in lijn te brengen met het IVRK. Zo is er uitdrukkelijk geen bereidheid om de leeftijdsgrens voor strafrechtelijke aansprakelijkheid te verhogen van twaalf naar veertien jaar, terwijl dit vanuit kinderrechten bezien wel de voorkeur zou verdienen. Ook wordt de kwetsbare positie van kinderen in politiecellen bepaald niet voortvarend ter hand genomen, terwijl hier al jaren aandacht voor wordt gevraagd door kinderrechtenorganisaties. En ook de rechtspraak van de Hoge Raad ten aanzien van de redelijke termijn in jeugdstrafzaken getuigt niet van de bereidheid om jeugdige verdachten de specifieke erkenning te geven die past bij een kinderrechtenconform jeugdstrafrecht. Daarnaast valt op dat het moment van inwerkingtreding van het nieuwe jeugdstrafrecht in Caribisch Nederland nog steeds onzeker is. En er blijven vragen over ongelijkheid en uitsluiting in en rondom het jeugdstrafrecht, als gevolg waarvan we niet gerust kunnen zijn over de vraag of ons jeugdstrafrechtsysteem niet feitelijk discriminatoir is of bepaalde kinderen uitsluit. ${ }^{8}$ Dit maakt dat we naar ons idee kritisch moeten zijn op wat is bereikt, maar vooral op wat er de komende jaren moet gebeuren.

Dit eerste nummer van Boom Strafblad (de voortzetting van het tot eind vorig jaar bestaande tijdschrift Strafblad $(\mathrm{Sdu}))$ kan daarbij vast inspirerend werken.

De verschillende auteurs laten hun licht schijnen op diverse aspecten van het jeugdstrafrecht, hetgeen naar wij hopen voor de lezer een aantrekkelijk caleidoscopisch beeld oplevert.

Van den Brink en Mijnarends onderzoeken in hun artikel wat de mogelijke implicaties zijn van het recente General Comment No. 24 van het Kinderrechtencomité op het Nederlandse jeugdstrafrecht, met name op het gebied van leeftijdsgrenzen en buitengerechtelijke afdoening - 'diversion'. Zij roepen de professionele actoren in de rechtspraktijk op actiever en explicieter gebruik te gaan maken van het IVRK en het General Comment.

Uit Beijerse doet in haar prikkelende bijdrage een appel op de wetgever en vraagt hem een voorbeeld te nemen aan voorgangers Cort van der Linden en Modderman en het kinderrechten-ideaal als leidend principe te hanteren bij het aanpakken van praktische vraagstukken.

Kan Nederland al op zijn lauweren rusten of is er nog wat werk aan de winkel? $U$ kunt het antwoord lezen in het artikel van feltes, waarin zij inzoomt op de rechtspositie van aangehouden minderjarige verdachten in de eerste fase van het strafrechtelijk onderzoek en deze naast de lat van Europese en internationale kinderrechten legt.

het recht voor om aan jeugdige verdachten geen raadsman toe te voegen in strafzaken die door het kantongerecht worden behandeld.

8. Zie bijv. Y. van den Brink e.a. Voorlopige hechtenis van jeugdigen in uitvoering. Een exploratief kwantitatief onderzoek naar rechterlijke beslissingen en populatiekenmerken, Nijmegen: Wolf Legal Publishers 2017. 
Jeugdrechter Van Kalveen doordenkt in haar bijdrage hoe het begrip 'kindvriendelijke rechtspraak' zich zou moeten doorvertalen naar de praktijk, het centrale thema daarbij is steeds 'participatie'.

Het IVRK heeft betrekking op kinderen en jongeren tot 18 jaar. Maar hoe zit het eigenlijk met jongvolwassenen, zouden die - gelet op de inzichten uit de ontwikkelingspsychologie en neurowetenschap - niet ook aanspraak moeten kunnen maken op die rechten? Schmidt pakt die vraag bij de kop in haar artikel.

We zijn ook verheugd $\mathrm{u}$ in dit nummer buiten Nederland te brengen, het vergelijken van je eigen vertrouwde rechtssysteem met dat van andere plekken op de wereld (ver of nabij) werkt altijd verrijkend. Bovendien maakt Nederland deel uit van een breder Koninkrijk dat zich in zijn geheel heeft gecommitteerd aan het IVRK. Charles laat $\mathrm{u}$ aan de hand van de onlangs verschenen UNICEF-publicatie Situation analysis on the Rights of Children and adolescents in the Caribbean Netherlands zien wat er op dit moment op jeugdstrafrechtelijk gebied speelt op Bonaire, St. Eustatius en Saba.

En na lezing van de bijdrage van Herbots en Van Rumst weet $\mathrm{u}$ hoe kinderrechtenproof het Vlaams jeugddelinquentierecht is en of Vlaanderen de ambitie om zich 'internationaal als goede praktijk in de aanpak van jeugddelinquentie te profileren' kan waarmaken.

Naast de artikelen over jeugdstrafrecht treft $\mathrm{u}$ in dit mooie nummer ook een niet-thematische bijdrage aan van de hand van Buisman. Zij exploreert de vraag aan de hand van welke criteria strafbaarstelling van ongewenst gedrag door de wetgever kan worden gelegitimeerd en gerechtvaardigd.

We komen tot een afronding, maar niet nadat eerst nog uw aandacht is gevraagd voor de bijzondere bijdrage van Gaakeer aan dit nummer. Gelet op het belang van literatuur voor het recht en de rechtsvinding zocht zij, op verzoek van de redactie, literaire fragmenten uit die illustratief zijn voor de ontwikkeling van de rechten van het kind. Haar inleiding op deze letterkundige intermezzi treft u meteen na dit redactioneel aan; de 'verluchtingen' komt u verspreid over het blad tussen de overige bijdragen tegen.

Tot slot, de relatie tussen kinderrechten en het strafrecht zal altijd een spannende blijven. En hoe meer vooruitgang er wordt geboekt, hoe lastiger de overblijvende uitdagingen kunnen zijn. Toch zou het Nederland sieren als het vol elan, met betrokkenheid en inclusief alle kinderen en jongeren binnen het Nederlandse Koninkrijk, blijft werken aan een jeugdstrafrecht dat volledig kinderrechtenproof is. Want zoals het in bovengenoemde pledge mooi staat geformuleerd: It is a moment for bold action! 